and two values can be derived, one $\left(\psi_{1}=\varphi_{1}+\varphi_{2}\right)$ representing a ground-state of lower energy than either interacting structure alone, and a second $\left(\psi_{2}=\varphi_{1}-\varphi_{2}\right)$ of highor energy. The molecule will, of course, normally exist in the ground-state, but may be excited to the higher one by absorption of light of appropriate frequency. Where two possible classical structures for a molecule differ in energy, the energy difference between ground-and excitedstates becomes greater, and such a dye will absorb at a shorter wave-length than otherwise.

These ideas have been successfully extended to the cyanine dyes, which can be represented as $\stackrel{+}{A} .-B \leftrightarrow A-\stackrel{+}{B}$. The more chemically similar the end groups $A$ and $B$ are, the less will the position of the absorption band deviate from the mean position of those for the two symmetrical dyes $A-A$ and $B-B$. The Brooker deviation series provides a striking confirmation.

Prof. Dewar also mentioned how these ideas explain the solvent effect on the position of absorption bands. There is nevertheless a flaw in the treatment, because interaction of pairs of classical structures can only take place through a series of intermediate structures. Analysis of the resonance between the complete set of structures is mathematically very difficult; but calculations have been done and they justify the conclusions of the simpler treatment. Easier to apply is the molecular orbital method, which has met with considerable success in accounting quantitatively rather than qualitatively for the colour of cyanine and other cationic or anionic dyes. Prof. Dewar elaborated the "free electron molecular orbital' approach, pointed out its limita. tions and successes, and went on to describe the 'perturbation molecular orbital' method. This is capable of accounting quantitatively for the light absorptions of aromatic hydrocarbons, as well as of cyanines, and related basic, acidic and azo dyes.

The relation between colour and constitution for the vat dyes, however, is much more difficult to interpret and possibly requires the development of more precise theoretical methods.

The papers of the symposium, with bibliographies, will be published by the Chemical Society, London, in Special Publication No. 4; this will include an account of the discussions, which were tape-recorded.

J. A. ELvIDGr

\title{
OBITUARIES
}

\section{Dr. H. E. Woodman}

Herbert Ernest Woodman died on February 13 at the age of sixty-six. He had been on the staff of the School of Agriculture at Cambridge for thirtysix years and was well known to generations of undergraduates. He was a leading euthority on animal nutrition in Great Britain.

After graduating at the University of Leeds, he spent another year working under Prof. J. B. Cohen in the Chemistry Department there. He was then awarded an 1851 Exhibition and spent two years at Göttingen under Prof. $O$. Wallach, working on the terpenes, and he received the degree of Ph.D. in 1914. Iater that year he joined the Animal Nutrition Research Institute, then at Leeds. He was awarded the D.Sc. degree of Leeds in 1921. Woodman at first worked with C. Crowther on the nitrogen metabolism of the dairy cow, and later with $\mathrm{H}$. W. Dudley on the origin of the proteins in milk. This work established the identity of euglobulin and pseudoglobulin, whether from serum or colostrum, but showed that lactalbumin and serum albumin were two distinct proteins. When the Institute was transferred to Cambridge in 1920, Woodman went with it. He was appointed University demonstrator in October 1926, University lecturer in October 1930, and reader in animal nutrition in 1950.

In the early 'twenties, ensilage was rapidly gaining adherents in Britain, but there was a complete lack of knowledge of the magnitude and nature of the chemical changes occurring in the silo. Woodman, therefore, in conjunction with A. Amos, carried out a detailed and systematic investigation of the conditions responsible for the production of different types of silage and devised methods of analysis that are still in common use. The results were published in the form of a bulletin ("Ensilage", Bull. 37, Ministry of Agriculture), which was revised periodically by
Woodman, and proved a great boon to the practical farmer as well as to the teacher.

In 1925, Woodman, with the encouragement of Prof. T. B. Wood, gathered together a team of young scientists to secure information concerning the nutritive value of pastures. This work continued over a period of twelve years and became a classic. It involved the determination of yield of dry matter, chemical composition, digestibility for sheep and pigs and the starch equivalent and protein equivalent per acre when the pasture was subjected to varying systems of management. A noteworthy finding was that young grass is a protein-rich concentrate, comparable in some respects with linseed cake. Living in Cambridge, with its lawns and playing fields, Woodman was attracted by the idea and possibility of the preservation of young grass for winter feeding by artificial drying. He carried out pioneer work in this field, and the present flourishing crop-drying industry is a tribute to this early work. Afterwards, investigations were made into the effect of management on the nutritive value of other forage crops like lucerne and kale. This information proved of inestim. able value during the war years.

Woodman was the author of about 170 scientific papers covering a wide range of subjects. He made a valuable contribution to our knowledge of such diverse subjects as sheep nutrition, the nutritive value of sugar beet by-products and the mechanism of cellulose digestion in the ruminant.

In 1930 Woodman and I published our first joint paper, the forerunner of many more, during a close research partnership that lasted more than twentyfive years. In 1936, the first of a series of eighteen papers on the nutrition of the bacon pig appeared. Great stress was laid in this paper on experimental technique and the importance of designing an experiment so that the results could be analysed statistically. It was shown that an individual-feeding trial could 
be four times as accurate as a corresponding groupfeeding trial. The question of the protein require. ments of pigs received early consideration. It was demonstrated that equally good results could be obtained, from the point of view of growth, economy of food conversion and carcass quality, when all-meal rations supplying only 7 per cent of white-fish meal were fed, as with diets much richer in protein. Moreover, it was shown that if the protein-rich concentrate was omitted altogether from the diet after $90 \mathrm{lb}$. live-weight, it was without the slightest effect on the rate of live-weight gain or on the leanness of the carcass. Considerable economies were therefore possible in the use of white-fish meal, which proved of great importance when supplies were short. The replacement of animal protein by vegetable protein plus minerals was also investigated.

On the death of Prof. T. B. Wood in 1930, Woodman became responsible for the sixth edition of "Rations for Livestock", the best-seller among the Bulletins of the Ministry of Agriculture. It became imperative in 1948 that the Bulletin should be almost entirely rewritten, and from this date Woodman assumed full responsibility as author. Woodman was also the author of the other bulletins- "Home Grown Feeding Stuffs" and "The Use of Oil Cakes and Extracted Meals" - which have lately been out of print. Finally, mention should be made of his contributions to Agriculture, during the War, of "Notes on Feeding Stuffs", which gave the results of research work at Cambridge and elsewhere, and were greatly appreciated by farmers and others.

No account of the work of Woodman would be complete without reference to his ability as a teacher. His great joy in life was in lecturing to the degree class at Cambridge. He was a born teacher and took infinite pains in the presentation of the material and had the gift of making a difficult subject seem easy.

He leaves a widow, a son and daughter, and a grandson.

R. E. Evans

\section{Dr. H. Wormald}

Harry Wormald, who died at his Maidstone home on December 10 last at the age of seventy-six, was distinguished for his pioneer work, over the past forty-five years, on the pathology of fruits and hops, and more particularly for his original researches on the two important groups of diseases, brown rot (Sclerotinia spp.) and bacterial canker (Pseudomonas mors-prunorum and Ps. prunicola Worm.), in both of which fields he became an authority of international repute.

Born a Yorkshireman, he first trained as a schoolteacher and for eight years taught a general curriculum in schools in Bradford and Leeds. It was therefore not until he was thirty years of age, in 1908, that with a Board of Education scholarship he went to London to read botany at the Royal College of Science (Imperial College of Science and Technology) under Prof. J. B. Farmer. Three years later he gained his A.R.C.S. and also the B.Sc. degree of the University of London with honours; and after a further year of research at the Royal College of Science, when he was awarded the diploms of the College, he went in 1911 to Wye College in Kent (University of London) as assistant in the Botany (Mycology) Department under E. S. Salmon. The dominating interest in fungal and bacterial diseases of fruits and hops which Wormald developed at Wye is reflected in the award of the D.Sc. degree in 1919 for his early publications on brown rot, and in his transfer in 1923 to the then young East Malling Research Station as the first head of its Plant Pathology Section. There he worked for twenty-two years under the inspiring directorship of $R$. $G$. Hatton, and as the beloved chief and mentor of a long succession of postgraduate students and colleagues. It was at East Malling that Wormald consolidated his early work on the brown rot and crown gall diseases, and initiated the brilliantly original etiological studies on the bacterial canker diseases of the stone fruits.

In 1936 Wormald was appointed assistant director at East Malling, and for ten years, from 1935, he edited the Station's Annual Report. In 1940 he became president of the British Mycological Society and was joint editor of the Transactions of that Society during 1931-45. He also served as a member of the Council of the Association of Applied Biologists (1937-39) and as a vice-president (1938-39).

In 1945, in his sixty-sixth year, Wormald finally retired from East Malling, and in the same year joined the staff of the Commonwealth Bureau of Horticulture and Plantation Crops, stationed at East Malling, where for seven years he exercised his linguistic gifts (he could translate fluently from seven languages, including Russian) as an abstractor of world horticultural literature.

In 1952, at the age of seventy-three, Wormald was obliged to retire from the Bureau because of the illness to which three years later he was to succumb, only, however, to continue at home, with the quiet and patient tenacity of purpose which characterized his whole research career, the preparation of new editions of his two principal works, the monograph "The Brown Rot Diseases of Fruit Trees" (Ministry of Agriculture and Fisheries), and the standard textbook on his subject, embracing the impressive corpus of his original research papers, "The Diseases of Fruits and Hops" (Crosby Lockwood and Son, Ltd.). With the devoted and unflagging support of his wife, these immense tasks were brought to a successful conclusion, and within six months of the publication of the new edition of his text-book he died.

$$
\text { R. V. HARRIS }
$$

\section{Mr. F. W. K. Gervers}

Frank Walter Kitchener Gervers was born on April 17, 1920. He went to school at Bradfield, where he became an enthusiastic member of the School Natural History Society and published a paper of unusual quality for a schoolboy on the biology of a small stream. When he left school in 1939 he followed a family tradition and joined the Regular Army. $\mathrm{He}$ served in the Royal Artillery in North Africa, Italy and India ; but his active military career was terminated by ill-health in 1946 and he decided to resume his interest in biology.

Gervers went to the University of Glasgow and during vacations worked in the laboratories at Pitlochry, Aberdeen and Lowestoft, and went to sea on the research vessels. After graduating he worked for a year with Dr. H. D. Slack on the biology of Loch Lomond, studying particularly the white fish or powan found there. In 1953, he joined the freshwater fisheries staff of the Ministry of Agriculture and Fisheries and carried out a most useful study of the food of coarse fish. He also took a large part in the 